\title{
Multi-Framework Implementation of the Problem Management Process
}

\author{
Ruben Pereira \\ Assistant Professor, ruben.filipe.pereira@iscte-iul.pt \\ Instituto Universitário de Lisboa (ISCTE-IUL), Avenida das Forças Armadas, 1649-026 Lisbon, Portugal
}

Isaías Scalabrin Bianchi

External Researcher, isaias.bianchi@gmail.com

Institute of Scientific Research, Universidad de LimaAv. Javier Prado Este 4600, Santiago de Surco 15023, Lima, Peru

\section{Virgínia Maria da Silva Araújo}

Assistant Professor, varaujo@uatlantica.pt

Atlantica University, School of Management Sciences, Health, IT \& Engineering,

Fábrica da Pólvora de Barcarena, 2730-036 Barcarena, Portugal

\begin{abstract}
$\mathrm{M}$

any different information technology frameworks have been proposed to assist organizations implementing information technology. However, these frameworks are complex, difficult to implement, and overlap with one another making their simultaneous implementation even more difficult to accomplish by organizations. This study proposes to develop an overlap-less maturity model that helps organizations

deal with the aforementioned problems. The model was applied and evaluated by experts at five organizations. This approach was recognized as useful, complete, and helpful in a multi-framework implementation by problem management (PM) experts. This research provides contributions for academics since it distinguishes itself from the existing studies in the body of knowledge and is a baseline for further investigation.
\end{abstract}

Keywords: IT frameworks; problem management; Maturity model; multi-framework implementation; frameworks overlap

Citation: Pereira R., Bianchi I.S., da Silva Araújo V.M. (2021) Multi-Framework Implementation of the Problem Management Process. Foresight and STI Governance, 15(3), 94-104. DOI: 10.17323/2500-2597.2021.3.94.104 


\section{Introduction}

Since the 1980s organizations have sought out competitive advantage and have become more cost-effective through the achievement of operational improvements [Kappelman et al., 2019]. The presence of computer and information technology (IT) in today's organizations has expanded dramatically [Carvalho et al., 2019a; Patón-Romero et al., 2018] and has pushed IT functions to become more service-oriented to be more cost-effective and aligned with business objectives [Carvalho et al., 2019b; Tan et al., 2010]. Nowadays, most organizations are deeply dependent upon IT in order to plan, design, deliver, operate, and control IT services offered to customers. IT departments are actually one of the most complex parts of an organization [Ayat et al., 2009]. To deal with the increase of IT complexity, many IT frameworks have been developed and proposed. All these frameworks have value to offer along with different strengths and weaknesses [Aguiar et al., 2018]. For example, the IT Infrastructure Library (ITIL) [Long, 2008], Control Objectives for Information and Related Technologies (COBIT) [ISACA, 2012], and Capability Maturity Model Integration for Services (CMMI-SVC) [SEI, 2010] are among the most popular ones.

Over the years, organizations have focused heavily on improving their IT processes to be able to bring remarkable benefits. One of the ways to improve IT processes is using IT frameworks and many organizations use them. Some researchers have reported the benefits of these frameworks [Huygh et al., 2018].

However, not only are IT frameworks seen as complex [Serenko et al., 2016], but the lack of assistance for customizing and implementing such frameworks make it difficult for organizations to choose one since it is unclear which IT framework better suits established IT environments [de Haes, van Grembergen, 2017]. Often the processes end by not being consistent and properly defined [Rohloff, 2008]. Plus, most of these IT frameworks overlap each other [de Haes et al., 2013]. This implies the duplication of investment, costs, and human resources for organizations [Gama et al., 2013]. However, they can be combined to narrow the gaps and then become more powerful than individual systems [Aguiar et al., 2018].

As pointed out by several authors such as [Aguiar et al., 2018; Schlarman, 2007] IT frameworks can easily overlap one another. Moreover, IT frameworks are complex to understand and implement [de Haes et al., 2013; Evelina et al., 2010; Herrera, Hillegersberg, 2019; Serenko et al., 2016].

By way of response, the maturity model (MM) concept was introduced to assess the level of a process [Becker et al., 2009]. Process MMs are being implemented by an increasing number of organizations [Uskarc, Demirörs, 2017] because they lay the groundwork as a measure to evaluate an organization's capabilities in a specific discipline [de Bruin et al., 2005]. As pointed out by [Beck- er et al., 2009], most MMs are considered too general and are usually not clearly defined and documented. Moreover, the current MMs do not address the overlap issue identified by several research studies [Sahibudin et al., 2008]. Among the most important processes proposed by IT frameworks is Problem Management (PM). However, implementing the PM process properly can be complex, long, expensive, and may cause PM implementation to fail [Sharifi et al., 2009; Pereira et al., 2012] leading to low quality service delivery. This means that PM can shape how customers see the entire organization and impact business considerably. Despite the popularity of some IT frameworks, there has been little academic research published to date about issues related to maturity model adoption and implementation [Cater-Steel et al., 2006; Jansen, 2020].

In accordance with the statements mentioned above, this study aims to develop an overlap-less and complete IT MM for the PM process grounded in ITIL, COBIT, and CMMI-SVC content following the theory proposed by [Becker et al., 2009] (which is based on the Design Science Research (DSR) methodology [Gregor, Hevner, 2013]).

\section{Theoretical Background}

\section{IT Frameworks}

The literature describes many IT frameworks, which are also called best practices and standard guidelines that assist the organization in the management of its technology infrastructure. The most relevant guidelines with the majority of citations are ITIL, COBIT and CMMI-SVC [Pereira, Mira da Silva, 2012].

ITIL is a set of best practices [Long, 2008] and one of the world's most widely accepted approaches to ITSM [Saarelainen, Jantti, 2016]. ITIL necessitates cultural changes and usually requires the use of specialists to enact and adapt it to each organizational context [Bovim et al., 2014]. The ITIL framework has been adopted by companies of all sizes and industries, including large, medium, and small businesses.

COBIT is an IT framework for designing, adopting, tracking, and optimizing IT governance and management procedures. It is one of the most widely used in the world. Its processes are divided into governance and management areas.

Finally, the CMMI-SVC [SEI, 2010] not only defines IT procedures but also a set of practices and goals that companies can use to implement their own sets of processes. A particular objective, according to the CMMI framework, defines the unique features that must be present to meet the process requirements. A specific practice is a description of an activity that is thought to be critical in achieving the associated goal [Aguiar et al., 2018]. Plus, this section also intends to present a brief analysis of each IT framework (Table 1). Since the PM process is included in each framework, it makes them suitable IT frameworks upon which to ground our proposal. 


\section{IT Maturity Models}

There is a consensus in the literature regarding the efficiency of MMs (Table 2). MMs depict a hierarchy of maturity levels for a certain class of objects (typically organizations or processes [Becker et al., 2009]) and the expected, required, or typical evolution paths of these objects in the form of discrete stages. This format allows for evaluating the applied processes through the prism of best management experience and a set of external parameters.

The initial work from AXELOS to measure service management processes started with the Process Maturity Framework (PMF) which was published and made available as an appendix of the ITIL "Service Design" publication [Long, 2008]. This PMF is used as a framework to evaluate the maturity of each of the Service Management processes independently or to measure the maturity of the overall Service Management process. [Long, 2008]. An updated model named "ITIL Maturity Model" presumes a self-assessment service to help organizations improve their IT service management within the ITIL framework [Aguiar et al., 2018]. This self-assessment is based on a series of questionnaires for each process and function in the ITIL service lifecycle. ${ }^{1}$

Following the research conducted by [Aguiar et al., 2018] as a reference, Tables 2 and 3 provide a short summary of the previously mentioned IT MMs so that readers can better understand how these MMs differ from one another. Almost all of the compared MMs have five levels. Two of them base their theories on ISO/IEC 15504. The most intriguing fact is that each of the identified MMs takes a unique approach, focusing solely on their own theory. It should be observed that none of these MMs address the problem of IT framework overlap.

One of the main advantages of the proposed approach is that the person doing the evaluation does not need to be an IT governance specialist because the analysis is done automatically [Simonsson et al., 2007]. The modeling language is based on COBIT and provides for the identification of entities and relations. The entities identified were: activities, KPI/KGI processes, documents, and roles [Aguiar et al., 2018]. Pereira and Mira da Silva [Pereira, Mira da Silva, 2010, 2011] proposed a model that is also based on CMMI-SVC. This MM was distinguished among others on the market at the time because it was designed exclusively to assist businesses in measuring their ITIL v3 maturity and leading them through the implementation of ITIL. The proposed IT Service Delivery MM, on the other hand, was a mechanism for formalizing and assessing IT Service Delivery Elements [Flores et al., 2011]. The authors of the aforementioned study established five levels of maturity, similar to CMMI-SVC. The adopted scale to score the maturity level is 1 to 5 . To better distinguish between maturity states, the authors add a "+" or a "-" whether the level is closer to being up or down. Vitoriano and Neto [Vitoriano, Neto, 2016] used a methodology based on the Process Maturity Framework (PMF), an MM defined in the ITIL (v2) reference model. To use this MM, some interviews with questions related to the five maturity levels, such as initial, repetitive, defined, managed, and optimized, are required; information was gathered on five fundamental ITSM processes.

More recently Aguiar et al. [Aguiar et al., 2018] developed a MM for the incident management (IM) process where the overlap issue was addressed and mitigated. The authors also took into consideration the main IT frameworks on the market. The results were exciting with great feedback from the experts. The study found that the main IT frameworks overlap each other almost 25\% regarding the IM process.

After analyzing the main IT frameworks and MMs among the literature, the authors were able reinforce the theory that most MMs ground their development on CMMI. Moreover, only one of the analyzed MMs take into consideration the overlap issue. It is the most recent study [Aguiar et al., 2018] where the researchers developed a MM for the IM process and incentivized future researchers to develop overlap-less MMs for the remaining IT processes. Therefore, such findings strengthen the aim and relevance of this research. It can be observed that the inquiry into the implementation of multi-frameworks and how it can be handled and measured has been financially rewarded [de Haes et al., 2013].

\section{Research Methodology}

Recently, Design Science Research (DSR) has gained importance and popularity in information systems. Many researchers have used DSR to develop an innovative approach in order to solve a specific and relevant organizational problem domain [Hevner et al., 2004]. The adopted research methodology was the DSR which has been incentivized to be used in a myriad of fields [Rai, 2017] including IT governance, covering a broad range of IT-related processes [Gregor, Hevner, 2013; de Maere, de Haes, 2017]. The key elements of DSR under investigation are the possibilities of discovering new fields of research, conducting testing and the validation of theories or building new theories. The purpose of this work is to to develop an overlap-less maturity model to solve a specific problem and help the organizatons. Therefore, DSR can be a suitable approach for this study. The proposed method was designed and evaluated following Peffers guidelines [Peffers et al., 2007] as you can see in the Figure 1.

\section{Proposal of an Overlap-less Maturity Model}

For the development of MMs, Becker et al. [Becker et al., 2009] identified a set of necessary requirements with which our proposal strictly complies (Table 4). In

${ }^{1}$ https://docplayer.net/655929-Itil-maturity-model-october-2013.html, accessed 15.07.2021. 


\section{Table 1. Comparing IT Frameworks}

\begin{tabular}{|l|l|l|l|}
\hline \multicolumn{1}{|c|}{ Model } & \multicolumn{1}{c|}{ ITIL V3 } & \multicolumn{1}{c|}{$\begin{array}{c}\text { COBIT } \\
\mathbf{5}\end{array}$} & \multicolumn{1}{c|}{ CMMI-SVC } \\
\hline Founder & OGC & $\begin{array}{l}\text { ISACA, } \\
\text { ITGI }\end{array}$ & $\begin{array}{l}\text { Software Engineering } \\
\text { Institute (SEI) }\end{array}$ \\
\hline Focus & IT Service & $\begin{array}{l}\text { IT } \\
\text { Service }\end{array}$ & IT Service \\
\hline PM & Yes & Yes & Yes \\
\hline $\begin{array}{l}\text { Name of } \\
\text { Process }\end{array}$ & $\begin{array}{l}\text { Problem } \\
\text { Management }\end{array}$ & $\begin{array}{l}\text { Manage } \\
\text { Problems }\end{array}$ & $\begin{array}{l}\text { Causal Analysis and } \\
\text { Resolution }\end{array}$ \\
\hline $\begin{array}{l}\text { Number of } \\
\text { Processes }\end{array}$ & 26 & 37 & 24 \\
\hline Source: authors. & & \\
\hline
\end{tabular}

addition, the development of the proposed PM MM was accomplished by following three steps: (1) Elicitation of PM activities from the most well-known IT frameworks; (2) Elimination of overlaps; and (3) definition of the maturity level for each elicited activity.

Phase 1: The first step focused on identifying all of the PM activities present in the ITIL, CMMI-SVC, and COBIT frameworks, as well as specifically identifying the IT frameworks supporting each elicited activity (Table 5). At the end of this phase, 349 activities had been gathered (Table 6). Table 7 shows a sample of its activities. The authors went through four iterations of fine-tuning the list to reach at a final consensus list.

Phase 2: The authors using the initial list concluded the phase (ant-overlap), moved on to the next, which involved a thorough identification of IT framework overlaps. During this phase, all activities were separated by process areas to make identifying overlaps easier. To demonstrate the outcome of this step, the authors present Table 7, which explains how the overlap elimination was carried out. By the end of this phase, $46 \mathrm{PM}$ activities had been identified as overlapping among the selected IT frameworks. This accounts for $13 \%$ of the initial set of activities gathered. It was possible to create a new list (post-overlap) of activities with 303 activities by merging activities and eliminating overlaps (Table 7).

Finally, to complete the proposal, the authors organized the final set of activities by maturity level. The maturity levels were assigned based on the adherence

Table 2. Comparison of Frameworks' MMs

\begin{tabular}{|l|l|l|l|}
\hline \multicolumn{5}{|c|}{ Table 2. Comparison of Frameworks' MMs } \\
\hline \multicolumn{1}{|c|}{ Model } & COBIT PAM & $\begin{array}{c}\text { CMMI- } \\
\text { SVC }\end{array}$ & \multicolumn{1}{c|}{ AXELOS } \\
\hline Number of levels & $0-5$ & SM:1-5 & $1-5$ \\
\hline Scope & Governance & CM:0-5 & IT Services \\
\hline Based on & ISO/IEC 15504 & IT Services & - \\
\hline Approach & Individual & - & Individual \\
\hline $\begin{array}{l}\text { Frameworks } \\
\text { overlap }\end{array}$ & Not addressed & Individual & Not addressed \\
\hline Source: authors. & \multicolumn{3}{|l}{} \\
\hline
\end{tabular}

of each activity to the CMMI-SVC description of maturity levels.

Using the same activities as in Table 5, the authors present Table 7 to illustrate how the maturity levels were assigned to each activity.

As an example, only one activity sample was provided for each existing maturity level. Here, the authors decided to follow the maturity level definitions of CMMI-SVC since they are used in the development of most MMs present in the literature. An activity classified as level 2 is considered a basic activity in the PM process since it is the first step for information collection. An activity classified as level 3 is mostly included among standards, procedures, or methods. An activity ranked as level 4 is focused on process measurement; such are usually metrics aimed at measuring a specific process aspect. Finally, an activity classified as level 5 is focused on the continuous improvement of processes and all activities involved in pursuing this kind of activity type. During the semi-structured interviews, a questionnaire was provided that consisted of all collected post-overlap activities, arranged by order of process (problem identification, problem logging, etc.), in order to become rational and concise throughout its course.

It should be stated that this approach only focuses on the framework activities. There are other relevant concepts (for example inputs, outputs, metrics, etc.) that organizations must still collect from the IT frameworks. However, by using our method first, organizations will have a clear vision of the core activities and the respective frameworks that they can then check later for further information. This does not substitute the IT frameworks. It may be seen as a complement to guiding organizations in further steps.

\section{Demonstration and Evaluation}

In order to demonstrate the proposed approach, the authors have searched for organizations with PM processes in place (up and running) and invited them to participate. Five organizations accepted the invitation to be assessed by the authors and to evaluate the proposed method. Both demonstration and evaluation were performed through semi-structured interviews

\begin{tabular}{|l|l|l|l|}
\hline \multicolumn{5}{|c|}{ Table 3. Comparison of MM Levels } \\
\hline \multicolumn{1}{|c|}{ Level } & COBIT PAM & \multicolumn{1}{c|}{ CMMI-SVC } & \multicolumn{1}{c|}{ AXELOS } \\
\hline 0 & Incomplete & - & - \\
\hline 1 & Performed & Initial & Initial \\
\hline 2 & Managed & Managed & Repeatable \\
\hline 3 & Established & Defined & Defined \\
\hline 4 & Predictable & $\begin{array}{l}\text { Quantitatively } \\
\text { Managed }\end{array}$ & Managed \\
\hline 5 & Optimizing & Optimizing & Optimizing \\
\hline 6 & - & - & - \\
\hline Source: authors. & & \\
\hline
\end{tabular}




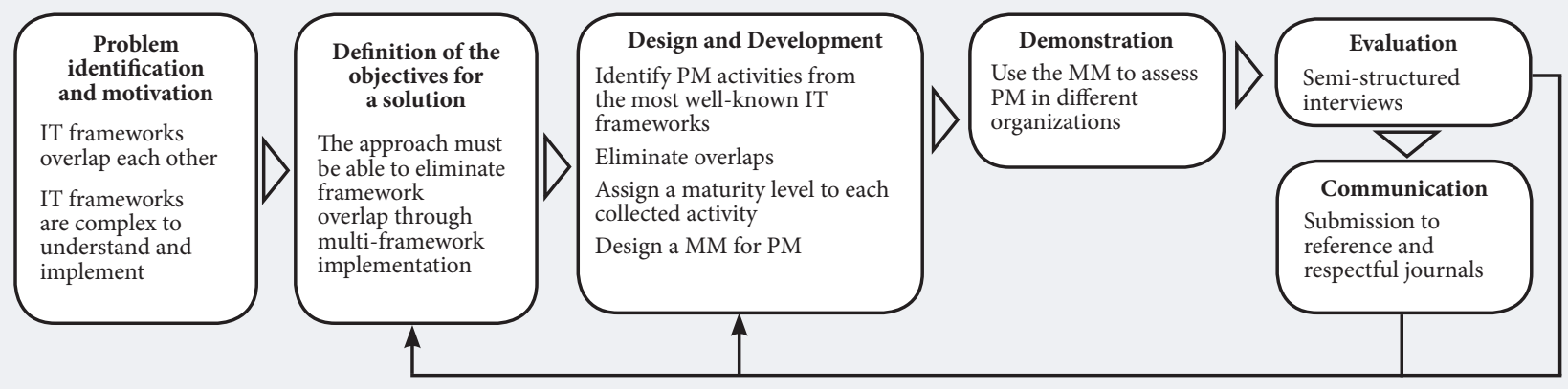

Source: adapted from [Peffers et al., 2007].

with experts from the respective organizations. In particular, the authors interviewed the PM process owner of each organization. During each interview, the list (post-overlap) was presented to the interviewee so he could confirm whether each activity had been implemented or not. The maturity level of each activity was not presented to avoid biased answers. At the end, the individual and global reports were sent to the interviewee. Any person/organization intending to apply the approach in the future should perform it in the same way.

\section{Data Collection and Analysis}

The interviews were conducted in different organizational contexts and with the most suitable decisionmakers to assess and provide information about the PM process. Details about the interviewees can be found in Table 8.

The interviews were conducted between March and July of 2018. In a total of five interviews (two via Skype and three in person). The average time required for each interview was one hour and 45 minutes. To prepare and help the interviewees before the assessment, a questionnaire was developed and delivered a few days before the interview. The questionnaire to frame the interview was developed in three parts. The first part contained general questions about the organization and the profile of interviewee. The second delved into the implementation of the activities. Finally the third part posed questions about the points of view and opinions of the interviewee regarding the PM MM. In Table 9 one can see organization's details. Organizational culture was described based on the theory proposed by [Matthyssens, Wursten, 2002].

Overall the assessed organizations have at least 1,400 employees and considerable IT departments. Some organizations did not permit the publication of some information. None of the assessed organizations had any sense of their maturity level. Such evidence brings even more relevance to this study.

According to [Pereira, Mira da Silva, 2012], in order to achieve a maturity level, organizations had to imple-

\section{Table 4. How the Proposed Approach Complies with the Becker Requirements}

\begin{tabular}{|l|l|}
\hline \multicolumn{1}{|c|}{ Requirement } & \multicolumn{1}{c|}{ Description } \\
\hline $\begin{array}{l}\text { Comparison with } \\
\text { existing MMs }\end{array}$ & $\begin{array}{l}\text { A comparison between IT frameworks should be made, mainly focusing on the most well-known and those } \\
\text { relevant for the case. }\end{array}$ \\
\hline Iterative procedure & $\begin{array}{l}\text { The identification of the first list of activities (1) was achieved through an iterative process. Plus, interviews can } \\
\text { be considered an interaction due the continuous feedback received from practitioners in order to improve this } \\
\text { process. }\end{array}$ \\
\hline Evaluation & $\begin{array}{l}\text { For the assessment of the approach, five semi-structured interviews were performed keeping in mind the } \\
\text { interactive process used in all interviews. }\end{array}$ \\
\hline $\begin{array}{l}\text { Multi-methodological } \\
\text { procedure }\end{array}$ & $\begin{array}{l}\text { Several methodologies were used for the creation of the model: literature review, cross frameworks analysis, } \\
\text { and semi-structure interviews. Plus, this research fulfills DSR procedures and Becker requirements. }\end{array}$ \\
\hline Problem definition & $\begin{array}{l}\text { There is no limitation in the application of the proposed PM MM unless PM practices already exist at the target } \\
\text { organization. It can be applied at any organization regardless of the classification presented in [Pereira et al., } \\
\text { 2013]. The main expected benefit is the prior identification of overlapping activities that may save resources in } \\
\text { future implementations of multi-frameworks. }\end{array}$ \\
\hline $\begin{array}{l}\text { Interim monitoring } \\
\text { and target presentation } \\
\text { of results }\end{array}$ & $\begin{array}{l}\text { Based on results collected throughout the assessment of the approach, it is possible to provide two types of } \\
\text { reports: an individual report for each organization and a global/cross-organization report. } \\
\text { The individual report can provide information regarding the current organizational maturity level and a } \\
\text { maturity roadmap including the required steps to reach the next level. Information can also be found about } \\
\text { achieved activities and the identification of which framework complies best as well as missing activities } \\
\text { identified in the roadmap. By using the roadmap, organizations are able to become more efficient at saving } \\
\text { resources in future multi-framework implementations. The global report is achievable by combining and cross- } \\
\text { referencing all information received from each assessment. }\end{array}$ \\
\hline \multicolumn{2}{|l}{} \\
\hline Source: authors. & \multicolumn{1}{|l}{} \\
\hline
\end{tabular}


Table 5. Sample of Pre-Overlap Activities among IT Frameworks

\begin{tabular}{|l|l|}
\hline \multicolumn{1}{|c|}{ Activity } & IT Framework \\
\hline Has the defect or problem been identified? & COBIT \\
\hline $\begin{array}{l}\text { Has a problem record been raised? If yes, } \\
\text { does the problem contain all relevant } \\
\text { details? }\end{array}$ & ITIL \\
\hline $\begin{array}{l}\text { After the problem is identified, do you } \\
\text { usually develop a suitable workaround? }\end{array}$ & CMMI-SVC \\
\hline $\begin{array}{l}\text { Do you usually analyze the change in } \\
\text { process performance of the affected } \\
\text { processes or sub-processes for the work? If } \\
\text { yes, do you measure it? }\end{array}$ & COBIT \\
\hline $\begin{array}{l}\text { Are the lessons learned from the review } \\
\text { presented at a service review meeting with } \\
\text { the business customer? }\end{array}$ & ITIL \\
\hline $\begin{array}{l}\text { Do you usually try to find a workaround to } \\
\text { temporarily solve the problem? }\end{array}$ & ITIL \\
\hline Has the problem been identified? & CMMI-SVC \\
\hline Source: authors. & \\
\hline
\end{tabular}

ment at least $75 \%$ of the activities of that corresponding level. Based on Figure 2, one can see level 2 is the most mature among the assessed organizations, followed by level 3 , level 4 , and level 5 , respectively. Overall organizations are more focused on definition and management activities but neglect metrics and measures to promote continuous improvement and predictive analysis.

An individual analysis is presented in Figure 3. All organizations have a similar maturity level, generally at level 2 (Managed). Level 5 (optimizing) is the lowest level, followed by level 4 (Quantitatively Managed) and finally level 3 (defined). Apparently, there is no visible disparity between the various types of organizations.

Despite the authors' conviction, none of the assessed organizations met the conditions to reach level 2 (75\%). The telecommunications company is the nearest one to achieve it. All organizations are at level 1 (initial). On average, the organizations tended to focus their efforts toward the first two levels, level 2 and 3 . To be considered a managed process (level 2) and reach level 3 (defined), most organizations would need to implement

Table 6. PM Activity Results after Applying the First Two Steps

\begin{tabular}{|c|l|c|c|}
\hline Model & PM process name & $\begin{array}{c}\text { Number of } \\
\text { activities (n) }\end{array}$ & $\begin{array}{c}\text { Percentage } \\
\text { (\%) }\end{array}$ \\
\hline ITIL & $\begin{array}{l}\text { Problem } \\
\text { Management }\end{array}$ & 153 & 44 \\
\hline COBIT & Manage Problems & 85 & 24 \\
\hline $\begin{array}{c}\text { CMMI- } \\
\text { SVC }\end{array}$ & $\begin{array}{l}\text { Causal Analysis and } \\
\text { Resolution }\end{array}$ & 111 & 32 \\
\hline Ant-Overlap activities & 349 & 100 \\
\hline \multicolumn{2}{|c|}{ Overlapped activities } & 46 & 13 \\
\hline \multicolumn{2}{|c|}{ Post-Overlap activities } & 303 & 87 \\
\hline Source: authors.
\end{tabular}

between $12 \%$ and $37 \%$ of the remaining activities. For some, it may be a considerable effort.

Overall, the software organization seems to be the least mature and the bank seems to be the most mature. The assessed bank is the only one with a similar percentage for levels 2 and 3 . All the other organizations have a considerable higher percentage of level 2. The telecommunications company achieved the highest percentage for level 2 but falls about $20 \%$ when considering level 3 while the bank has a more stable and balanced percentage among the first two levels.

Another interesting finding is that, apparently, organizations are aligned with MM theory. According to the MM theory, a previous level is crucial for achieving the next level. This means that it would not make sense, for example, to have a higher percentage of level 3 than level 2. Based on that, the authors may argue that organizations are aligned with these guidelines. None of the organizations have a maturity level with higher percentage than the previous one. Such a fact indicates that despite none of the assessed organizations being at level 2, they are implementing the process in a coordinated and balanced way.

Additional insights can be obtained regarding the IT frameworks adopted within each organization. Most of the interviewed organizations (80\%) pointed to ITIL as the officially adopted IT framework with the last organization adopting CMMI-SVC (20\%). Such a finding is aligned with previous studies claiming that ITIL was one of the most adopted IT frameworks on the market [Long, 2008; Saarelainen, Jantti, 2016]. Plus, the authors also found that ITIL activities are the most implemented in number and percentage. Table 10 illustrates all the insights gathered from the assessments regarding the adoption of each IT framework.

\section{Evaluation}

After completing the interview process, the interviewees were invited to provide some feedback by answering some questions in order to evaluate the approach and consequently the problem statement of our research. As illustrated in Table 11, from a global perspective, the opinion was positive. Some interviewees mentioned that it was exhaustive but complete which is quite understandable. However, it was agreed upon among the interviewees that the proposed method is useful in providing a complete vision of the PM process based on the three most-known IT frameworks. No activity was considered absent, which validates the first (1) and second (2) steps performed to develop the approach.

\section{Discussion}

Despite the existence of several IT frameworks to help organizations increase IT efficiency, such are seen as complex [Serenko et al., 2016], difficult to implement [de Haes, van Grembergen, 2017], prone to overlap one another [Schlarman, 2007; Pereira, Mira da Silva, 2011], 
Table 7. Demonstration of the Merging Process

\begin{tabular}{|l|l|l|l|l|}
\hline \multicolumn{1}{|c|}{ Activity } & $\begin{array}{l}\text { Maturity } \\
\text { Level }\end{array}$ & \multicolumn{1}{|c|}{ ITIL } & \multicolumn{1}{c|}{ CMMI-SVC } & COBIT \\
\hline Are the problems identified? & 2 & $\begin{array}{l}\text { Has a problem record been } \\
\text { raised? }\end{array}$ & $\begin{array}{l}\text { Has the defect or problem } \\
\text { been identified? }\end{array}$ & $\begin{array}{l}\text { Has the problem been } \\
\text { identified? }\end{array}$ \\
\hline $\begin{array}{l}\text { Do you usually try to find } \\
\text { a workaround to solve the } \\
\text { problem? }\end{array}$ & 3 & $\begin{array}{l}\text { Do you usually try to find a } \\
\text { workaround to temporarily } \\
\text { solve the problem? }\end{array}$ & - & $\begin{array}{l}\text { After the problem is } \\
\text { identified, do you usually } \\
\text { develop a suitable } \\
\text { workaround? }\end{array}$ \\
\hline $\begin{array}{l}\text { Do you usually analyze the } \\
\text { change in the performance of } \\
\text { the affected processes or sub- } \\
\text { processes for the work? If yes, } \\
\text { do you measure it? }\end{array}$ & 4 & - & $\begin{array}{l}\text { Do you usually analyze the } \\
\text { change in the performance of } \\
\text { the affected processes or sub- } \\
\text { processes for the work? If yes, } \\
\text { do you measure it? }\end{array}$ & - \\
\hline $\begin{array}{l}\text { Are the lessons learned from } \\
\text { the review presented during } \\
\text { a service review meeting with } \\
\text { the business customer? }\end{array}$ & 5 & $\begin{array}{l}\text { Are the lessons learned from } \\
\text { the review is presented during } \\
\text { a service review meeting with } \\
\text { the business customer? }\end{array}$ & - & - \\
\hline Source: authors. & 5 & \\
\hline
\end{tabular}

Table 8. Details about the Interviewees

\begin{tabular}{|l|l|c|c|c|}
\hline \multicolumn{1}{|c|}{ Country } & \multicolumn{1}{|c|}{ Position } & $\begin{array}{c}\text { Experience in IT } \\
(\text { years })\end{array}$ & $\begin{array}{c}\text { Duration of interview } \\
(\mathbf{H})\end{array}$ & \multicolumn{1}{c|}{ Procedure } \\
\hline Portugal & IT Manager & 18 & $2 \mathrm{~h} 40$ & Face to face \\
\hline Portugal & IT Team Leader & 8 & $1 \mathrm{~h} 50$ & Face to face \\
\hline USA & Application Support Lead & 12 & $1 \mathrm{~h} 30$ & Virtual \\
\hline Portugal & IT Director & 16 & $1 \mathrm{~h} 12$ & Virtual \\
\hline Portugal & IT Director & 20 & \multicolumn{3}{l}{ Face to face } \\
\hline Source $:$ authors.
\end{tabular}

\section{Table 9. Factor Analysis and Details about the Interviewee's Organization}

\begin{tabular}{|l|l|l|l|l|l|l|}
\hline \multicolumn{1}{|c|}{ Industry } & \multicolumn{1}{|c|}{ Size } & IT Employees & \multicolumn{1}{c|}{ Market } & \multicolumn{1}{c|}{ IT Strategy } & \multicolumn{1}{c|}{ IT Structure } & \multicolumn{1}{c|}{ Culture } \\
\hline Telecommunication & 2100 & 400 & Worldwide & Flexibility & Decentralized & Pyramidal \\
\hline $\begin{array}{l}\text { Energy, } \\
\text { Automation and } \\
\text { Telecommunication }\end{array}$ & 1400 & 28 & Worldwide & Flexibility & Decentralized & Pyramidal \\
\hline Pharmaceutical & 42000 & 1300 & Worldwide & Efficiency & Federal & Contest \\
\hline Software & 13000 & - & Worldwide & - & - & - \\
\hline Banking & - & - & Wordwide & Flexibility & Federal & Pyramidal \\
\hline Source: authors.
\end{tabular}

\section{Figure 2. Average Implemented Activities (\%)}

a) percentage b) number

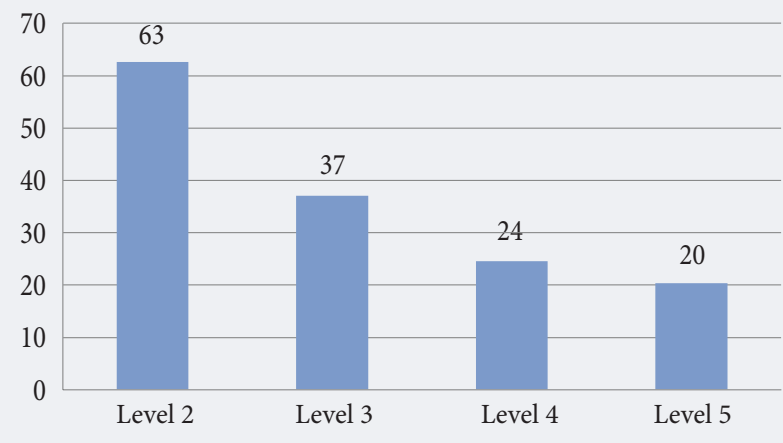

Source: authors.

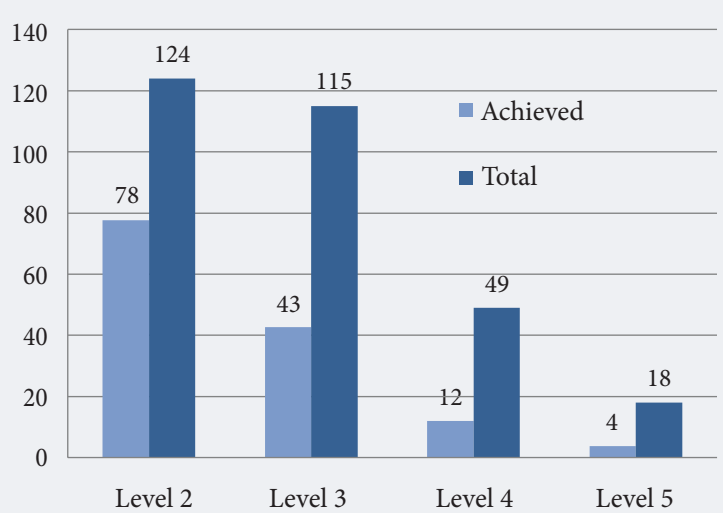


Figure 3. Maturity Level of Each Organization (activities achieved by type of organization)

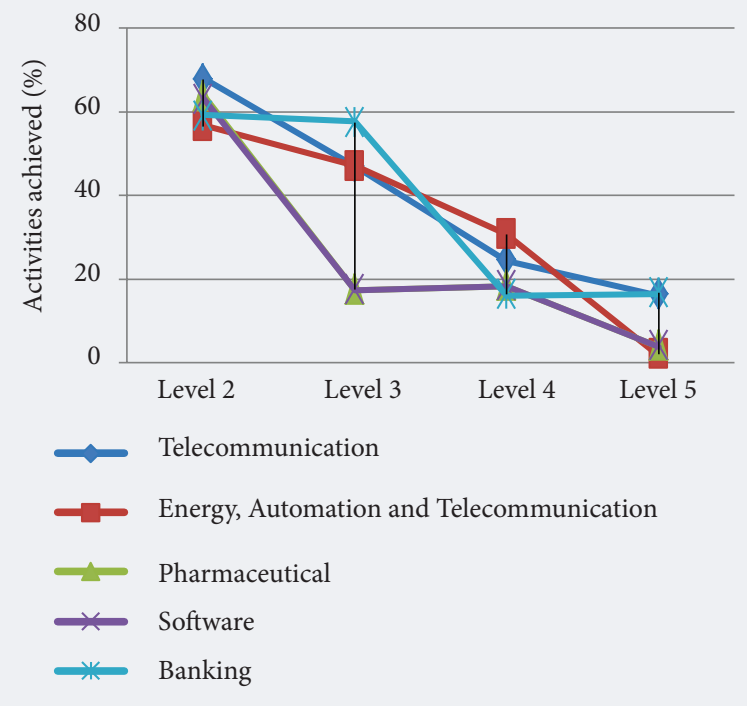

Source: authors.

and generic [Pereira, Mira da Silva, 2012]. Therefore, this research proposes an approach that mitigates some of the existing gaps in multi-framework implementation such as framework overlap and complexity. This research not only confirms the gaps found earlier but aim to solve them with a suggested method that may help organizations in multi-framework implementations. All the interviewees found the approach useful (demonstrated in practice) and complete (no activity was thought to be missing). According to [de Haes et al., 2013; Aguiar et al., 2018], multi-framework implementation is a real challenge. Many organizations are not yet aware of their implementation and fail to yield the best results from them.

A PM MM was then developed by the authors merging all details and knowledge of the three most wellknown IT frameworks on the market regarding PM process. During the initial process in the creation of the model, these three IT frameworks (COBIT, CMMISVC and ITIL) were analyzed. In the end this research confirmed the existence of overlaps between the IT
Table 11. PM MM Evaluation

\begin{tabular}{|c|l|l|l|}
\hline $\begin{array}{c}\text { Interview } \\
\text { number }\end{array}$ & Completeness & $\begin{array}{c}\text { Missing } \\
\text { activities }\end{array}$ & Usefulness \\
\hline 1 & $\begin{array}{l}\text { Too long / } \\
\text { Overtired }\end{array}$ & No & Yes \\
\hline 2 & Very complete & No & Yes \\
\hline 3 & Yes & No & Very \\
\hline 4 & Very & No & Yes \\
\hline 5 & Yes & No & Yes \\
\hline Source: authors. & & \\
\hline
\end{tabular}

frameworks. About 13\% of the elicited PM activities were common to at least two IT frameworks.

This research provides novel insights for academics given that a new approach absent from the literature was developed merging all the main IT service management frameworks regarding the Problem Management process and tested at real organizations. This may now be assumed as a base for further investigation for the remaining IT service management processes. This research also contributes to the performance of professionals since they now have a tool to assess their Problem Management process maturity. It will help them achieve higher levels of maturity and be aware of current overlaps. Consequently, they may save resources that can be allocated to other processes.

\section{Adding Knowledge by Crossing Studies}

Cross-referencing similar studies and findings is an interesting exercise that can be used to evolve the body of knowledge and bring new insights to the scientific community. As previously stated, a similar study [Aguiar et al., 2018] was performed in the past but focused on the IM process instead of PM. The current research was also motivated by the future work proposed by the previous investigation. Table 12 and Table 13 present the information combined from both studies. It is interesting to note that in both studies (Table 12) the highest overlap percentage belongs to the activities common to the three IT frameworks while the lowest belongs to the activities common between COBIT and CMMI-SVC. On the other hand, other findings can be drawn from Table 13. It seems that, when looking for

\section{Table 10. Analysis of the Adoption of Each IT Framework within the Model}

\begin{tabular}{|c|c|c|c|c|c|c|c|c|}
\hline Models & ITIL & $\begin{array}{l}\text { CMMI- } \\
\text { SVC }\end{array}$ & COBIT & $\begin{array}{c}\text { ITIL\& } \\
\text { CMMI- } \\
\text { SVC }\end{array}$ & $\begin{array}{l}\text { ITIL\& } \\
\text { COBIT }\end{array}$ & $\begin{array}{l}\text { CMMI- } \\
\text { SVC \& } \\
\text { COBIT }\end{array}$ & All & Total \\
\hline Overall activities (number) & 101 & 89 & 73 & 7 & 11 & 3 & 19 & 303 \\
\hline Overall activities (\%) & 33.33 & 29.37 & 24.09 & 2.31 & 3.63 & 0.99 & 6.27 & 100 \\
\hline PM process overlap (\%) & & & & 2.31 & 3.63 & 0.99 & 6.27 & 13.20 \\
\hline Average implemented activities (number) & 90 & 72 & 65 & 4 & 9 & 2 & 15 & 257 \\
\hline Average/Total implemented activities (\%) & 29.70 & 23.76 & 21.45 & 1.32 & 2.97 & 0.66 & 4.95 & - \\
\hline Average/Overall implemented (\%) & 89.11 & 80.90 & 89.04 & 57.14 & 81.82 & 66.67 & 78.95 & - \\
\hline
\end{tabular}


Table 12. Cross-Study: Overlapped Activities (\%)

\begin{tabular}{|l|c|c|c|c|c|}
\hline \multicolumn{1}{|c|}{ Overlapped Activities } & $\begin{array}{c}\text { ITIL \& CMMI } \\
\text { SVC }\end{array}$ & ITIL \& COBIT & $\begin{array}{c}\text { CMMI-SVC \& } \\
\text { COBIT }\end{array}$ & All & Total \\
\hline Incident Management & 5.3 & 2.4 & 1.4 & 14.5 & 23.6 \\
\hline Problem Management & 2.31 & 3.63 & 0.99 & 6.27 & 13.20 \\
\hline $\begin{array}{l}\text { Note: } \text { the colored cells in dark and light represent the minimum and maximum of some specific frameworks. } \\
\text { Source: authors. }\end{array}$
\end{tabular}

Table 13. Cross-Study: Implemented Activities (\%)

\begin{tabular}{|c|c|c|c|c|c|c|c|}
\hline Implemented Activities & ITIL & CMMI-SVC & COBIT & $\begin{array}{c}\text { ITIL\& CMMI- } \\
\text { SVC }\end{array}$ & $\begin{array}{l}\text { ITIL\& } \\
\text { COBIT }\end{array}$ & $\begin{array}{c}\text { CMMI-SVC } \\
\text { \& COBIT }\end{array}$ & All \\
\hline Incident Management & 70.1 & 79.0 & 72.2 & 77.4 & 62.5 & 71.4 & 84.1 \\
\hline Problem Management & 89.11 & 80.90 & 89.04 & 57.14 & 81.82 & 66.67 & 78.95 \\
\hline
\end{tabular}

both processes, organizations have different preferences regarding which IT frameworks to implement.

\section{Conclusion}

This research aims to create an approach to help organizations in multi-framework implementation by eliminating overlaps among IT frameworks. To do so, the authors chose one of the most relevant IT processes (PM) and developed an overlap-less PM MM. The validity of this new approach was confirmed by applying and evaluating it at five different organizations.

This research confirms and reinforces the issue of IT framework overlaps previously identified by other researchers. From the 349 PM activities elicited, 46 activities were identified as being areas of overlap among the chosen IT frameworks. Almost 15\% of all activities are present in at least two of the three IT frameworks analyzed in this research (Table 10).

All the interviewees considered the approach useful and complete. They confirmed that implementing an IT framework is not straightforward and having a method to help them in multi-framework implementation would be very useful [de Haes et al., 2013; Aguiar et al., 2018]. By recognizing the proposed method as complete, the interviewees (PM experts) confirm that it is helpful. Looking at the assessed organizations, four of them (80\%) pointed to ITIL as the official IT framework. The fifth organization (20\%) adopted CMMI. It is interesting to note that despite none of the assessed organizations reaching level 2 , they have been implementing the PM process in a balanced way.

From a cross studies analysis, both processes (IM and PM) tend to have the highest percentage of activities overlapped by all the IT frameworks and the lowest percentage of activities common between COBIT and CMMI-SVC.

This research also has some limitations. The authors think that the previous conclusions may change when considering the remaining IT processes and within different organizational contexts. Built on such limitations, future work may assess the model at more organizations and consequently develop similar MMs for the rest of the existing IT processes. It is also authors' conviction that, having an integrated model able to cover most of the adopted IT processes could be very useful and at the same time challenging, which stands as a reason to continue this research.

\section{References}

Aguiar J., Pereira R., Vasconcelos J. B., Bianchi I. (2018) An Overlapless Incident Management Maturity Model for MultiFramework Assessment (ITIL, COBIT, CMMI-SVC). Interdisciplinary Journal of Information, Knowledge, and Management, 13, 137-163. https://doi.org/10.28945/4083

Ayat M., Sharifi M., Sahibudin S., Ibrahim S. (2009) Adoption factors and implementation steps of ITSM in the target organizations. Paper presented at the 2009 Third Asia International Conference on Modelling \& Simulation 25-29 May 2009 Bundang, Indonesia. https://doi.org/10.1109/AMS.2009.114

Becker J., Knackstedt R., Pöppelbuß J. (2009) Developing Maturity Models for IT Management. Business \& Information Systems Engineering, 1(3), 213-222. https://doi.org/10.1007/s12599-009-0044-5

Bianchi I.S., Sousa R.D., Pereira R. (2017) IT Governance Mechanisms at Universities: An Exploratory Study. Paper presented at the Twenty-third Americas Conference on Information Systems, August 2017, Boston, USA. https://www.researchgate.net/ publication/319141074_IT_governance_Mechanisms_at_Universities_An_Exploratory_Study, accessed 16.05.2021.

Bovim A., Johnston K., Kabanda S., Tanner M., Stander A. (2014) ITIL adoption in South African: A Capability Maturity view. Paper presented at the E-Skills for Knowledge Production and Innovation Conference 2014, Cape Town, South Africa. http://proceedings.e-skillsconference.org/2014/e-skills049-060Bovim759.pdf, accessed 17.06.2021. 
Carvalho J.V., Rocha Á., Abreu A. (2019a) Maturity Assessment Methodology for HISM M - Hospital Information System Maturity Model. Journal of Medical Systems, 43(2), 35. https://doi.org/10.1007/s10916-018-1143-y

Carvalho J.V., Rocha Á., van de Wetering R., Abreu A. (2019b) A maturity model for hospital information systems. Journal of Business Research, 94, 388-399. https://doi.org/10.1016/J.JBUSRES.2017.12.012

Cater-Steel A., Tan W.-G., Toleman M. (2006) Challenge of adopting multiple process improvement frameworks. Paper presented at the 14th European Conference on Information Systems, ECIS 2006, Göteborg, Sweden, 2006. https://www.researchgate. net/publication/221408576_Challenge_of_adopting_multiple_process_improvement_frameworks, accessed 10.05.2021.

De Bruin T., Freeze R., Kulkarni U., Rosemann M., Freeze R., Carey W.P. (2005) Understanding the Main Phases of Developing a Maturity Assessment Model. Paper presented at the 16th Australian Conference on Information Systems (ACIS 2005). http://aisel.aisnet.org/acis2005, accessed 08.06.2021.

De Haes S., van Grembergen W. (eds.) (2017) Strategic IT governance and alignment in business settings. Hershey, PA: IGI Global. https://doi.org/10.4018/978-1-5225-0861-8

De Haes S., van Grembergen W., Debreceny R.S. (2013) COBIT 5 and Enterprise Governance of Information Technology: Building Blocks and Research Opportunities. Journal of Information Systems, 27(1), 307-324. https://doi.org/10.2308/isys50422

De Maere K., De Haes S. (2017) Is the Design Science Approach fit for IT Governance Research? Paper presented at the 16th European Conference on Research Methodology for Business and Management Studies, June 2017, Dublin. https://www. proquest.com/openview/d898b4819205b18146e1bddd65bd615a/1 ?pq-origsite=gscholar\&cbl=1796413\#: :text=The\%20 results\%20suggest\%20that\%20top,elements\%20in\%20their\%20research\%20design, accessed 24.01.2021.

Evelina E., Pia G., David H., von Würtemberg L.M., Waldo R.F. (2010) Process improvement framework evaluation. Paper presented at the 17th International Conference on Management Science \& Engineering, 24-26 November 2010, Melbourne, VIC, Australia. DOI: 10.1109/ICMSE.2010.5719823.

Flores J., Rusu L., Johannesson P. (2011) A Maturity Model of IT Service Delivery. Paper presented at the International Conference on Information Resources Management (CONF-IRM), June 2011. https://aisel.aisnet.org/cgi/viewcontent. cgi? article $=1009 \&$ context $=$ confirm2011, accessed 12.06.2021.

Gama N., Sousa P., da Silva M.M. (2013) Integrating Enterprise Architecture and IT Service Management. In: Building Sustainable Information Systems (eds. H. Linger, J. Fisher, A. Barnden, C. Barry, M. Lang, C. Schneider), Heidelberg, Dordrecht, London, New York: Springer, 153-165. https://doi.org/10.1007/978-1-4614-7540-8_12

Gregor S., Hevner A.R. (2013) Positioning and Presenting Design Science Research for Maximum Impact. MIS Quarterly, 37(2), 337-355. https://doi.org/10.2753/MIS0742-1222240302

Herrera M., van Hillegersberg J. (2019) Using Metamodeling to Represent Lean Six Sigma for IT Service Improvement. Paper presented at the 21st IEEE Conference on Business Informatics (CBI), 15-17 July 2019, Moscow, Russia. https://doi. org/10.1109/CBI.2019.00034

Hevner A.R., March S.T., Park J., Ram S. (2004) Design Science in Information Systems Research. MIS Quarterly, 28(1), 75-105. https://doi.org/10.2307/25148625

Huygh T., De Haes S., Joshi A., van Grembergen W. (2018) Answering key global IT management concerns through IT governance and management processes: A COBIT 5 view. Paper presented at the 51 st Hawaii International Conference on System Sciences. DOI: $10.24251 / \mathrm{HICSS} .2018 .665$

ISACA (2012) COBIT 5: Enabling Processes, Schaumburg, IL: Information Systems Audit and Control Association.

ISACA (2013) COBIT 5: Process Assessment Model (PAM), Schaumburg, IL: Information Systems Audit and Control Association.

Jansen S. (2020) A focus area maturity model for software ecosystem governance. Information and Software Technology, 118, 106219. https://doi.org/10.1016/j.infsof.2019.106219

Kappelman L., Johnson V., Torres R., Maurer C., McLean E. (2019) A study of information systems issues, practices, and leadership in Europe. European Journal of Information Systems, 28(1), 26-42. https://doi.org/10.1080/0960085X.2018.1497929

Long J.O. (2008) ITIL ${ }^{\circledast}$ Version 3 at a Glance: Information Quick Reference, Heidelberg, Dordrecht, London, New York: Springer, https://doi.org/10.1007/978-0-387-77393-3

March S.T., Smith G.F. (1995) Design and natural science research on information technology. Descision Support Systems, 15(4), 251-266. https://doi.org/10.1016/0167-9236(94)00041-2

Matthyssens P., Wursten H. (2002) Internal Marketing. Cross-cultural marketing (eds. R. Rugimbana, S. Nwankwo), Toronto, ON: Thompson Educational Publishing, pp. 243-256.

Patón-Romero J.D., Baldassarre M.T., Rodríguez M., Piattini M. (2018) Green IT Governance and Management based on ISO/ IEC 15504. Computer Standards \& Interfaces, 60, 26-36. https://doi.org/10.1016/J.CSI.2018.04.005

Peffers K.E.N., Tuunanen T., Rothenberger M.A., Chatterjee S. (2007) A Design Science Research Methodology for Information Systems Research. Journal of Management Information Systems, 24(3), 45-77. https://doi.org/10.2307/40398896

Pereira R., Almeida R., Mira da Silva M. (2013) How to Generalize an Information Technology Case Study. Paper presented at the 8th Design Science Research in Information Systems and Technology (DESRIST), June 11-12, 2013, Helsinki, Finland. https://doi.org/10.1007/978-3-642-38827-9_11

Pereira R., Mira da Silva M. (2010) ITIL maturity model. Paper presented at the 2010 5th Iberian Conference on Information Systems and Technologies (CISTI), June 16-19, Santiago de Compostela, Spain.

Pereira R., Mira da Silva M. (2011) A Maturity Model for Implementing ITILv3. Paper presented at the IEEE 15th International Enterprise Distributed Object Computing Conference Workshops, 29 August - 2 September 2011, Helsinki, Finland. DOI: $10.1109 /$ EDOCW.2011.30 
Pereira R., Mira da Silva M. (2012) Designing a new integrated IT governance and IT management framework based on both scientific and practitioner viewpoint. International Journal of Enterprise Information Systems (IJEIS), 8(4), 1-43. https://doi. org/doi:10.4018/jeis.2012100101

Rai A. (2017) Diversity of Design Science Research. MIS Quarterly, 41(1), 3-18. https://aisel.aisnet.org/misq/vol41/iss1/2, accessed 19.11.2020.

Rohloff M. (2008) A Reference Process Model for IT Service Management. Paper presented at the AMCIS 2008 Conference, 14-17 August 2008, Toronto, ON, Canada. http://aisel.aisnet.org/amcis2008/2, accessed 19.11.2020.

Saarelainen K., Jantti M. (2016) Quality and human errors in IT service infrastructures - Human error based root causes of incidents and their categorization. Paper presented at the 11th International Conference on Innovations in Information Technology (IIT), 1-3 November 2015, Dubai, United Arab Emirates. https://doi.org/10.1109/INNOVATIONS.2015.7381541

Sahibudin S., Sharifi M., Ayat M. (2008) Combining ITIL, COBIT and ISO/IEC 27002 in order to design a comprehensive IT framework in organizations. Paper presented at the 2nd Asia International Conference on Modelling \& Simulation (AMS), 13-15 May 2008, Kuala Lumpur, Malaysia. https://doi.org/10.1109/AMS.2008.145

Schlarman S. (2007) Selecting an IT control framework. Information Systems Security, 16(3), 147-151. https://doi. org/10.1080/10658980701225440

SEI (2010) CMMI ${ }^{\circledast}$ for Services, Version 1.3 CMMI-SVC, V1.3 Improving processes for providing better services, Pittsburgh, PA: Software Engineering Institute.

Serenko A., Bontis N., Hull E. (2016) An application of the knowledge management maturity model: The case of credit unions. Knowledge Management Research \& Practice, 14(3), 338-352. https://doi.org/10.1057/kmrp.2014.37

Sharifi M., Ayat M., Ibrahim S., Sahibuddin S. (2009) The most applicable KPIs of problem management process in organizations. International Journal of Simulation: Systems, Science and Technology, 10(3), 77-83. http://ijssst.info/Vol-10/ No-3/paper8.pdf, accessed 22.06.2021.

Simonsson M., Johnson P., Wijkström H. (2007) Model-Based IT Governance Maturity Assessments with Cobit. Paper presented at the 15th European Conference on Information Systems, ECIS 2007, St. Gallen, Switzerland. http://aisel.aisnet. org/ecis2007, accessed 17.11.2020.

Tan W.-G., Cater-Steel A., Toleman M. (2010) Implementing IT service management: A case study focusing on critical success factors. Journal of Computer Information Systems, 50(2), 1-12. https://doi.org/10.1080/08874417.2009.11645379

Uskarc1 A., Demirörs O. (2017) Do staged maturity models result in organization-wide continuous process improvement? Insight from employees. Computer Standards and Interfaces, 52, 25-40. https://doi.org/10.1016/j.csi.2017.01.008

Venable J.R., Pries-Heje J., Baskerville R. (2017) Choosing a Design Science Research Methodology. Paper presented at the 28th Australasian Conference on Information Systems, 4-6 December 2017, Hobart, Australia. http://hdl.handle. net/20.500.11937/70119, accessed 18.05.2020.

Vitoriano M.A.V., Neto J.S. (2016) Information technology service management processes maturity in the Brazilian Federal direct administration. Journal of Information Systems and Technology Management, 12(3), 663-686. https://doi.org/10.4301/ S1807-17752015000300009

Webster J., Watson R.T. (2002) Analyzing the Past to Prepare for the Future: Writing a Literature Review. MIS Quarterly, 26(2), 13-23. https://doi.org/10.1.1.104.6570 